\title{
Computer-controlled in-vitro simulation of multiple dosing regimens
}

\author{
B. Ledergerber, J. Blaser and R. Lüthy \\ Division of Infectious Diseases, Department of Medicine, \\ University Hospital Zürich, CH-8091 Zürich, Switzerland
}

\begin{abstract}
The bactericidal effect of gentamicin on Pseudomonas aeruginosa ATCC 27853 was investigated in a computer controlled dynamic in-vitro model, which allows the simultaneous simulation of three different dosing regimens for several days. The same total dose reduced cfu-counts of Pseudomonas aeruginosa most effectively, when administered with peak concentrations of $32 \mathrm{mg} / \mathrm{l}$ every $32 \mathrm{~h}$, whereas the other dosing regimens with peak concentrations of $16 \mathrm{mg} / \mathrm{l}$ every $16 \mathrm{~h}$ and $8 \mathrm{mg} / \mathrm{l}$ every $8 \mathrm{~h}$ were distinctly less effective following the second and subsequent doses. It was shown that the use of a microcomputer facilitates the in-vitro investigation of multıple dosıng regimens but counting of cfu cannot be substituted by automatic measurements of turbidity when rapid bactencidal effects occur.
\end{abstract}

\section{Introduction}

With few exceptions, such as gonorrhoea or uncomplicated unnary tract infections, the treatment of infectious diseases requires administration of antibiotics in multiple doses for several days. It therefore seems appropriate to perform $n$-vitro investigations of multiple dosing regimens which can yield important information concerning the bactericidal or bactenostatic action of the second or subsequent doses and the possibility of emerging resistance, phenomena which escape the in-vitro studies of single doses.

The use of a microprocessor with the capacity to control simultaneously multiple independent sets facilitates the performance of long-term expenments and improves their reproducibility. The feedback of certain data to the computer offers additional advantages such as (i) information concerning the actual state of the experiment by displaying and recording turbidity data which can be used as a guideline for dilutıng the samples for cfu-determinations and (ii) maintenance of constant pharmacokinetic conditions by verification of liquid levels.

Turbidity data can further be used to initiate automatically active intervention in an experiment, e.g. when lack of action of a drug is detected

The purpose of the present study was to prove the feasibulity of the computer controlled in-vitro model to determine the effect of three different multıple dosing regimens of gentamicin on the viable counts of Pseudomonas aeruginosa.

\section{Materials and methods}

Medıa

Mueller-Hinton broth (MHB) and Mueller-Hınton agar (MHA) were obtained from Difco (Brunschwig AG, Basel, Switzerland). MHB was supplemented with $\mathrm{Mg}^{++}$and $\mathrm{Ca}^{++}$(MHB-S) according to NCCLS standards (1983). 
Antibiotics

Gentamicin laboratory reference powder was obtained from Schering (Essex Chemie, Luzern, Switzerland).

\section{Bacterial strain}

Log-phase cultures of Ps. aeruginosa ATCC 27853 were photometrically adjusted by diluting them with MHB-S to yield a final inoculum of $10^{5} \mathrm{cfu} / \mathrm{ml}$. Glass flasks (volume $125 \mathrm{ml}$ ) were filled with $100 \mathrm{ml}$ of the bacterial suspension. The minimal inhibitory concentration (MIC) of gentamicin in MHB-S was $2.0 \mathrm{mg} / \mathrm{l}$.

\section{Viable counts of bacteria}

To detect $>100 \mathrm{cfu} / \mathrm{ml}$, three drops of $20 \mu \mathrm{l}$, each from appropriate tubes of serial tenfold dilutions, were plated on MHA. Less than $100 \mathrm{cfu} / \mathrm{ml}$ were quantified by membrane filtration of $1 \mathrm{ml}$ and $10 \mathrm{ml}$ of undiluted samples, yielding a sensitivity of $0.5 \mathrm{cfu} / \mathrm{ml}$. Filters were washed with $100 \mathrm{ml}$ of $0.9 \% \mathrm{NaCl}$ in water to eliminate residual drug and placed on MHA. Viable counts were not adjusted for the loss which occurred through the dilution with drug free broth.

\section{Simulation of multiple dosing regimens}

The in-vitro model (designated apparatus model I) described by Grasso et al. (1978) was modified by adding a second peristaltic pump which drained the culture flask and thereby maintained a constant fluid level (Figure 1, pump 3). In addition, this pump

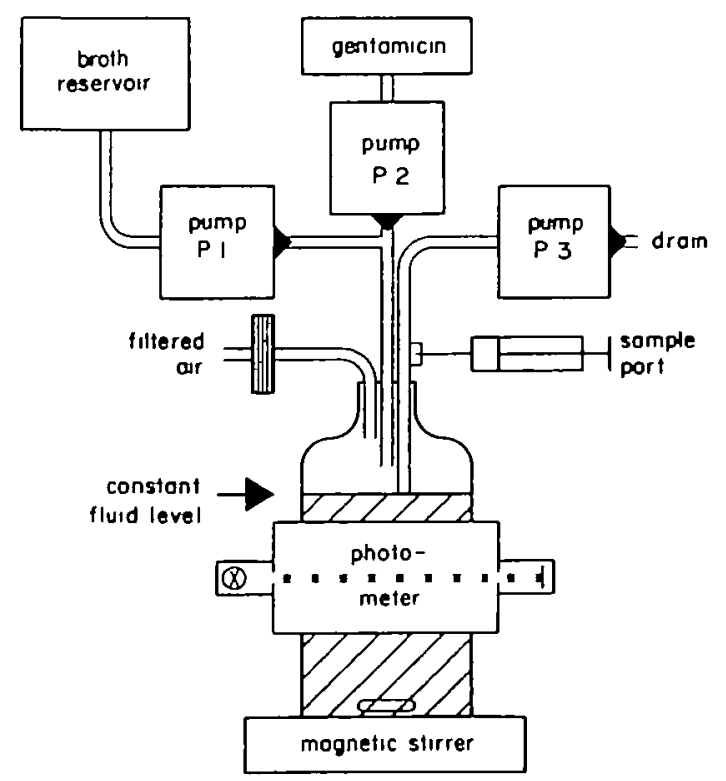

Figure 1. Single set of the in-vitro model. Pump speed of pump PI was adjusted to produce the destred elımination half-hife, whereas pump P3 (drain) was suctioning at a higher flow rate to maintain the constant volume and to provide the ventilation of the head space with filtered aur (pore size: $0.2 \mu \mathrm{m}$ ). Pump P2 was operated according to the dosage regimens. 


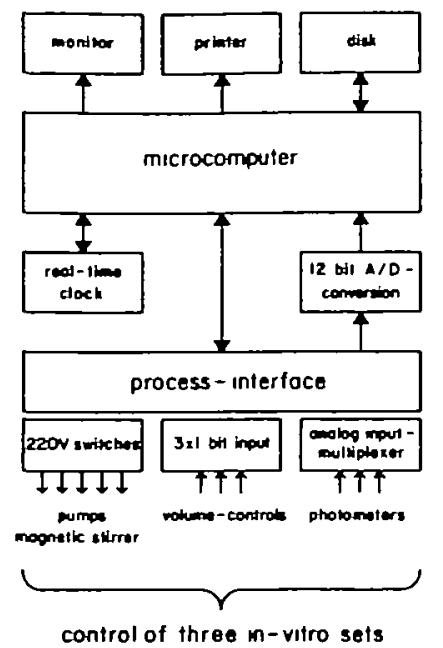

Figare 2. Diagram of the computer system The process interface was designed to control simultaneously three un-vitro sets as shown in Figure 1

provided continuous ventilation of the head space of the culture flask through a port for filtered air which allowed aerobic growth conditions. Three sets of the in-vitro model were simultaneously operated in an incubator at a temperature of $37.0^{\circ} \mathrm{C}$, simulating three multiple dosing regimens ( $\mathrm{A}, \mathrm{B}$ and $\mathrm{C}$ ) with identical total doses, which produced peak gentamicin concentrations of 8,16 and $32 \mathrm{mg} / \mathrm{l}$ at dosage intervals of 8,16 and $32 \mathrm{~h}$, respectively. The infusion periods were $30 \mathrm{~min}$ each. Human one-compartment pharmacokinetics with an elimination half-life of $2 \cdot 2 \mathrm{~h}$ were simulated by continuous dilution with drug free broth.

\section{Turbidimetry}

Three photometers were built with extra-bright light-emitting diodes, wave-length $660 \mathrm{~nm}$ (Stanley ESBR 5501, Dewald AG, Zürich, Switzerland), matched pairs of photodiodes (United Detector Technology PIN-3DP, Traco AG, Zürich, Switzerland) and a $\log$ ratio amplifier (LOG100, Burr-Brown AG, Rüschlikon, Switzerland) providing a compensated operation with a threshold for the detection of $>200,000 \mathrm{cfu} / \mathrm{ml}$. Turbidity was measured in each culture flask over a path length of $4.6 \mathrm{~cm}$ and recorded on the disc of the computer at $5 \mathrm{~min}$ intervals.

\section{Computer control}

An Apple II plus computer (Apple Computer Inc., Cupertıno, California), supplied with a specially designed interface was used to control simultaneously three sets of the in-vitro model as shown in Figure 2.

\section{Results}

\section{Multiple dosing regimens}

The gentamicin concentration versus time curves for the three different dosing regimens are displayed in Figure 3. The resulting viable counts and optical density 


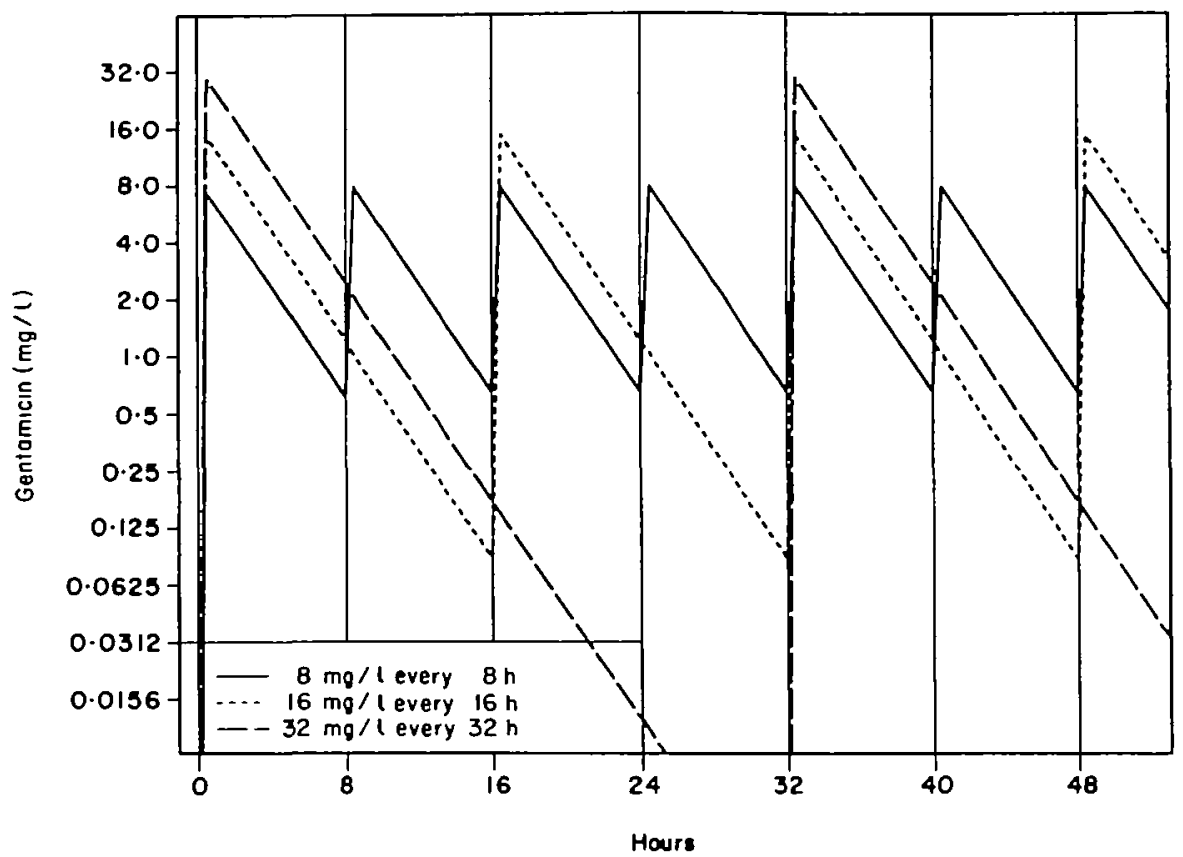

Figure 3. Concentration versus tume curves of the three gentamian dosing regimens $A, B$ and $C$ with an identucal total dose yrelding peak concentrations of 8,16 and $32 \mathrm{mg} / \mathrm{l}$ at intervals of 8,16 and $32 \mathrm{~h}$, respectuvely

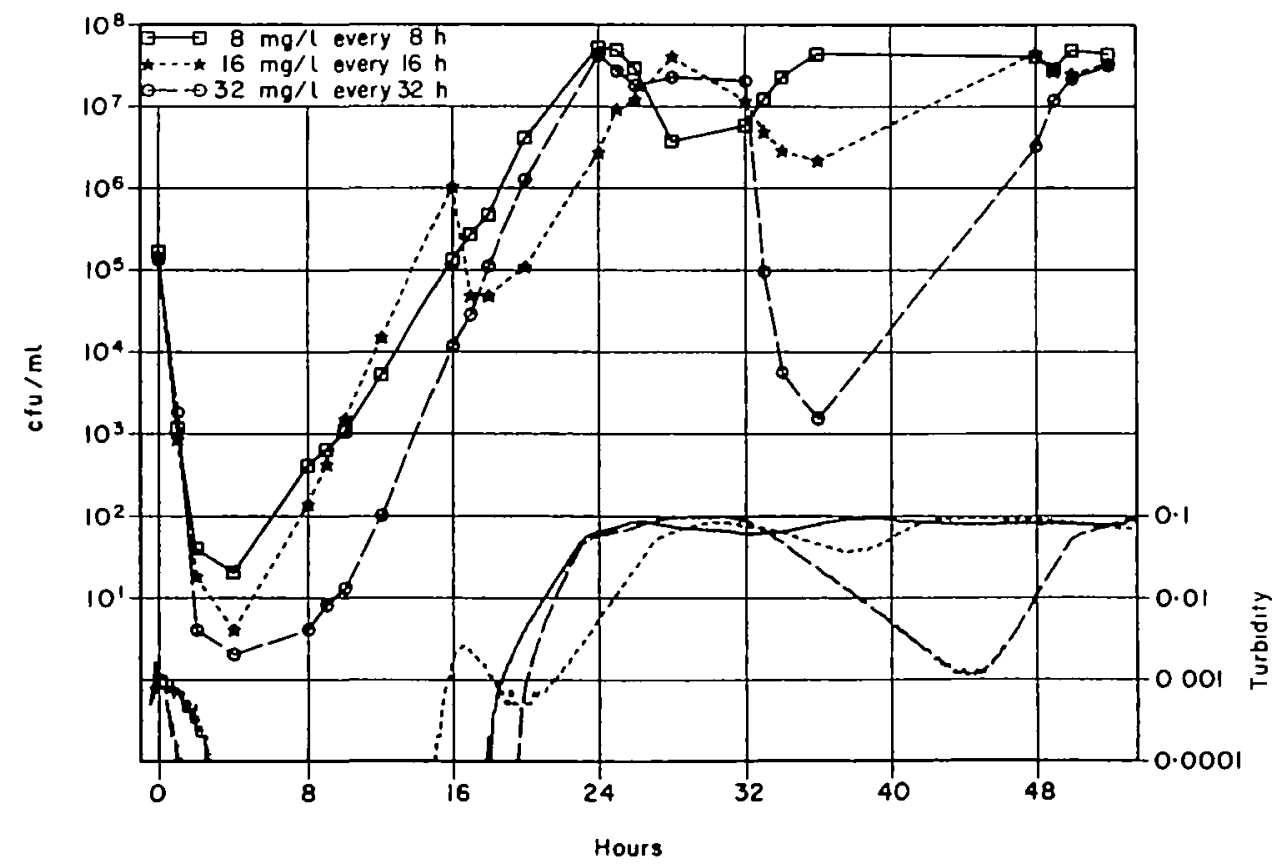

Figure 4. Cfu and turbidity versus ume curves of Ps aeruginosa ATCC 27853, exposed to the three dosing regimens of gentamicin which are displayed in Figure 3 The photometers, operated at $660 \mathrm{~nm}$, yielded a threshold of the detection of $>200,000 \mathrm{cfu} / \mathrm{ml}$ 
versus time curves (Figure 4) show a rapid and dose dependent decline after the first dose, followed by regrowth within 4 to $8 \mathrm{~h}$. Apart from a slight reduction of cfu at $24 \mathrm{~h}$, the subsequent doses of regimen A $(8 \mathrm{mg} / \mathrm{l}$ peak concentrations every $8 \mathrm{~h})$ showed no apparent bactericidal activity. The second and third dose of regimen $\mathrm{B}$, yielding a peak concentration of $16 \mathrm{mg} / \mathrm{l}$ at 16 and $32 \mathrm{~h}$ were marginally effective, and at $48 \mathrm{~h}$, the effect of the fourth dose was completely lacking. This is in contrast to the obvious bactencidal effect of the second dose of regimen $C(32 \mathrm{mg} / 1$ peak concentration) at $32 \mathrm{~h}$ which resulted in a decrease of approximately $4 \log \mathrm{cfu}$, comparable to the effect of the first dose.

Turbidity versus time curves showed a good correlation with the cfu-counts when growth occurred. In periods of rapid bactericidal action (e.g. regimen $\mathrm{C}$ at $32 \mathrm{~h}$ ), turbidity was determined by the washout of dead bacteria through dilution with drug free broth and deviated markedly from the determinations of viable counts.

\section{Discussion}

The effect of multiple doses of gentamicin on Ps. aeruginosa ATCC 27853 was studied in a computer controlled in-vitro model. It was demonstrated that identical total doses of gentamicin were most effective, when administered at intervals of $32 \mathrm{~h}$. Although the concentration of gentamicin for that regimen (C) was below the MIC for approximately $3 / 4$ of the dosage interval, cfu's did not exceed the counts observed with regimen $A$ within the first $24 \mathrm{~h}$. Indeed, the long period of subinhibitory concentrations may be the reason for the retained bactericidal action of the second dose.

The on-line measurement of turbidity showed a good correlation with $>200,000 \mathrm{cfu} / \mathrm{ml}$ as long as growth occurred and was very useful as a guideline for dilutıng the samples for cfu-determinations. Due to insufficient sensitivity and the inability to quantify rapid bactericidal effects, as observed with aminoglycosides, the substitution of cfu-counts by turbidity measurements is not advisable.

The use of a microcomputer was a time-saving and reliable method to simulate multiple dosing regimens for several days. Limitations in simultaneously performing multiple dosing regimens were found to be the processing of samples, increasing number of pumps and space in the incubator.

Further development of the model includes the analogue control of pump speeds to simulate combination therapies of drugs with different half-lives and the automatic use of turbıdity data to evaluate optımal timing of synergistic combinations.

\section{References}

Grasso, S, Meinardi, G., Carner, I. \& Tamassia, V. (1978). New in vitro model to study the effect of antubiotic concentration and rate of elimination on antibacterial activity Antumicrobial Agents and Chemotherapy 13, 570-6

Tentatıve Standard. (1983). Methods for dilution antımıcrobıal susceptibility tests for bacteria that grow aerobically National Committee for Clınical Laboratory Standards, Villanova, $\mathrm{Pa}$ 